\title{
PARTITION OF UNESTERIFIED FATTY ACIDS IN NORMAL AND NEPHROTIC SYNDROME SERUM AND ITS EFFECT ON SERUM ELECTROPHORETIC PATTERN ${ }^{1}$
}

\author{
BY ELEAZAR SHAFRIR 2 \\ (From the Section on Metabolism, National Heart Institute, National Institutes of Health, \\ Bethesda, Md., and the Department of Biochemistry, Hebrew University-Hadassah \\ Medical School, Jerusalem, Israel)
}

(Submitted for publication July 25, 1958 ; accepted August 28, 1958)

The electrophoretic pattern of the serum in the nephrotic syndrome is marked by decreased concentrations of albumin and elevated concentrations of alpha $2_{2}$ and beta-globulins. A large portion of the excess lipid in nephrotic serum migrates at $\mathrm{pH} 8.6$ in the alpha $_{2}$ region, whereas normally the major part of the lipid is found in the beta position. This abnormal finding has never been adequately explained. Thus, Swahn remarks that "the electrophoretic separation of alpha ${ }_{2}$ - from beta-globulin in nephrotic sera is often poor and it is difficult to decide whether there is a pathological lipoprotein fraction migrating quicker than normal beta lipoprotein" (1).

Unesterified fatty acids (UFA) have been recently demonstrated to be of considerable importance in lipid transport and metabolism (2). In normal serum these acids are generally considered to be predominantly carried by albumin. However, Gordon (3) and others (4-6) have shown that UFA can increase the electrophoretic mobility of serum lipoproteins when liberated in vivo by heparin-released lipoprotein lipase or when added directly to the serum in vitro. It was inferred by the above investigators that at these high levels, a significant fraction of the UFA became associated with the lipoproteins, thereby increasing their negative electrostatic surface charge.

The present paper reports on direct measurements of the partition of UFA resulting from the competitive binding of UFA by the albumin and lipoprotein components of the serum. The distribution of UFA in normal sera was compared with the distribution in pathologic sera, in which the total UFA concentration does not deviate appreciably from normal, but in which the relative

\footnotetext{
1 Preliminary reports appeared in Bull. Res. Coun., Israel, 1957, 6A, 307, and Fed. Proc. 1958, 17, 309.

2 Hadassah Medical Organization Research Fellow.
}

albumin and lipoprotein concentrations are so altered as to produce a marked shift in UFA equilibrium. It could be shown indeed, that such conditions prevail in the nephrotic syndrome and to a lesser extent in other hyperlipemias and appear to be responsible for the irregular electrophoretic pattern of serum lipoproteins observed in these states.

\section{MATERIALS AND METHODS}

The blood samples were obtained from fasting subjects and promptly chilled. Separation and analysis of the sera was started within two hours of blood withdrawal.

Unesterified fatty acids (UFA) were first determined by the method of Dole (7) and later by a modification (8) of the method of Gordon (9) as indicated in the text. In the extraction mixture used by Gordon, part of the glacial acetic acid has been replaced by acetic anhydride. The sample was introduced into the modified solvent without previous lyophilization. After the dehydration was completed, the washing and titration procedures of Gordon were followed.

Total protein was measured by the biuret method of Weichselbaum (10). Serum lipids were determined by the method of Bragdon (11). Total lipid values were obtained by dividing the dichromate oxidation value by 17.7. Total esterified fatty acids were estimated according to Stern and Shapiro (12).

In the initial experiments the procedure used to measure the amount of albumin-bound UFA was to separate the serum albumin by precipitation of the globulins at 60 per cent ammonium sulfate saturation (13). A few milliliters of serum were mixed with an equal volume of the ammonium sulfate solution, placed in a cellophane bag and dialyzed against the same solution at $22^{\circ} \mathrm{C}$. with stirring for 16 hours. The contents of the bag were then centrifuged at $10,000 \times \mathrm{G}$, the supernatant filtered when necessary and the ammonium sulfate dialyzed off. Electrophoretic examination in barbital buffer at $\mathrm{pH} 8.6$ revealed that about 95 per cent of the supernatant protein moved as one component with the mobility of albumin. Lipid analysis has shown that the albumin thus separated contained less than $0.02 \mathrm{Gm}$. of plasma lipids other than UFA per Gm. of protein. The molar ratio of UFA to 
albumin was obtained from the determination of UFA and protein contents of the isolated albumin sample. The amount of UFA bound to the total serum albumin was calculated from the above ratio and from the albumin concentration in the given serum as estimated from the electrophoretic pattern.

Preparative ultracentrifugation of sera was performed as described by Havel, Eder and Bragdon (14) and Bragdon, Havel and Boyle (15). Aliquots of the sera were brought to densities of $1.019,1.063$ and 1.21 , respectively, by diluting with concentrated solutions of potassium bromide. A few experiments were performed using deuterium oxide or a solution of sucrose in deuterium oxide to raise the density and are referred to in the text. After spinning in the No. 40.3 rotor of the Model L Spinco ultracentrifuge, the lipoproteins floated to the top of the tube, were collected quantitatively, and the UFA directly extracted using the modified method of Gordon (8). Aliquots of infranatants at each density were extracted similarly. The recoveries of the extracted UFA at each density ranged from 90.2 to 115.5 per cent of the value determined on the whole serum before centrifugation (60 experiments). However, in most experiments the recovery was within 5 per cent of the original value. The percentage of UFA bound to the lipoproteins $d<1.019, d=1.019$ to 1.063 and $d=1.063$ to 1.21 was obtained by difference. For example, the per cent UFA in the $d=1.019$ to 1.063 class equals per cent UFA in lipoproteins flotated at $d<1.063$ minus per cent UFA in lipoprotein of $\mathrm{d}<1.019$.

For enrichment of nephrotic sera with albumin, Bovine Fraction V (Armour Lot No. K11511) was used. Prior to use its UFA content was reduced by brief treatment with methanol $(16)$ at $-5^{\circ} \mathrm{C}$. to $0.38 \mathrm{Eq}$. per $\mathrm{M}$ of albumin, assuming a molecular weight of 69,000 for albumin. ${ }^{3}$ The albumin thus obtained was electrophoretically homogenous when examined in barbital buffer at $\mathrm{pH} 8.6$ and its mobility was $-5.8 \times 10^{-5} \mathrm{~cm}^{2}$ Volt. $^{-1} \mathrm{sec}^{-1}$.

Moving boundary electrophoresis was performed in a Perkin Elmer apparatus 38A, equipped with the PhilpotSvensson optical system. The sera were diluted threeto fourfold and dialyzed for 24 hours against barbital buffer, $\mathrm{pH} 8.6$, ionic strength 0.1 at $4^{\circ} \mathrm{C}$. The electrophoretic mobilities were calculated from the descending boundary patterns, while the relative concentrations of the resolved components were derived from the ascending boundaries. Duplicate determinations performed on two samples of the same serum gave results differing up to 5 per cent.

Paper electrophoresis was performed on Whatman 3 MM strips in the apparatus of Köiw, Wallenius and Grönwall (18). The proteins were stained with amido black and the lipoproteins with oil red $O$. The stained strips were quantitated in a photometric automatic recorder (Spinco Analytrol) with 600 and $500 \mathrm{~m} \mu$ filters, respectively.

3 After this work was completed a more efficient procedure for preparation of UFA-free albumin was published (17).

\section{RESULTS}

\section{The UFA content of nephrotic serum}

The mean UFA content of 12 nephrotic sera as measured by the method of Dole was $0.505 \mathrm{mEq}$. per L. (range, 0.290 to $0.740 \mathrm{mEq}$. per L.). These values were not significantly different from the normal level of $0.521 \mathrm{mEq}$. per L. (range, 0.385 to $0.688 \mathrm{mEq}$. per L.) as found on 10 subjects.

\section{Albumin-bound UFA of normal and nephrotic serum}

The albumin-bound UFA in serum, measured on samples obtained at 60 per cent ammonium sulfate saturation, are indicated in Table $\mathrm{I}$. More UFA per mole of isolated albumin was found in nephrotic sera than in normal sera. However, the percentage of the total serum UFA bound to nephrotic albumin was on the average only 35.7 per cent (12 sera) as compared with 77.6 per cent in 10 normal sera. Thus, in spite of normal serum UFA levels, considerable amounts of UFA are present in nephrotic serum in a form other than UFA-albumin complex. As suggestive evidence from electrophoretic studies (4-6) pointed to lipoproteins as alternative acceptors of UFA, determination of lipoproteinbound UFA was undertaken.

\section{Lipoprotein-bound UFA in normal, nephrotic and hyperlipemic sera}

Percentages of total serum UFA bound to the three main classes of lipoproteins isolated by means of ultracentrifugal flotation are presented in Table II. In comparison with normal sera, the distribution pattern of UFA is markedly altered in nephrosis and to a lesser extent in hyperlipemia. The percentage of lipoproteinbound UFA increases severalfold in these conditions. To illustrate the competitive nature of the binding of UFA by serum albumin and lipoproteins, values of total lipoprotein-bound UFA and of the total lipid to albumin ratio in the same serum are given in the table. It appears that the shift of UFA into the lipoproteins is dependent on the magnitude of this ratio.

This may be further illustrated by graphic presentation of similar relationship obtained in 
TABLE I

Albumin-bound unesterified fatty acids (UFA) in nephrotic sera

\begin{tabular}{|c|c|c|c|c|c|}
\hline Subject & & $\underset{\text { albumin* }}{\text { Serum }}$ & $\begin{array}{c}\text { Serum } \\
\text { UFAt }\end{array}$ & $\begin{array}{c}\text { Molar } \\
\text { ratioł } \\
\text { UFA/alb. }\end{array}$ & $\begin{array}{l}\% \text { of serum } \\
\text { UFA bound } \\
\text { to albumin }\end{array}$ \\
\hline $\begin{array}{r}1 \\
2 \\
3 \\
4 \\
5 \\
6 \\
7 \\
8 \\
9 \\
10 \\
11 \\
12\end{array}$ & $\begin{array}{l}\text { Primary nephrotic syndrome } \\
\text { Primary nephrotic syndrome } \\
\text { Primary nephrotic syndrome } \\
\text { Primary nephrotic syndrome } \\
\text { Primary nephrotic syndrome } \\
\text { Primary nephrotic syndrome } \\
\text { Nephrotic stage of glomerulonephritis } \\
\text { Nephrotic stage of glomerulonephritis } \\
\text { Nephrotic stage of lupus erythematosus } \\
\text { Nephrotic stage of dermatomyositis } \\
\text { Advanced diabetic nephropathy } \\
\text { Nephrotic syndrome in pregnancy }\end{array}$ & $\begin{array}{c}\text { Gm./100 ml. } \\
1.41 \\
0.65 \\
0.86 \\
1.38 \\
1.87 \\
0.28 \\
1.53 \\
2.87 \\
0.73 \\
1.63 \\
1.16 \\
1.60\end{array}$ & $\begin{array}{c}m E q . / L . \\
0.60 \\
0.39 \\
0.42 \\
0.48 \\
0.46 \\
0.29 \\
0.41 \\
0.74 \\
0.52 \\
0.53 \\
0.70 \\
0.52\end{array}$ & $\begin{array}{l}1.10 \\
1.21 \\
0.91 \\
1.10 \\
0.86 \\
1.60 \\
0.87 \\
0.98 \\
1.17 \\
0.94 \\
1.15 \\
0.95\end{array}$ & $\begin{array}{l}37.0 \\
28.7 \\
26.6 \\
44.7 \\
49.8 \\
22.0 \\
36.6 \\
54.3 \\
23.6 \\
41.2 \\
21.9 \\
41.8\end{array}$ \\
\hline \multicolumn{2}{|c|}{ Mean $\pm S . D$. of 10 normals } & $\begin{array}{r}3.45 \\
\pm 0.36\end{array}$ & $\begin{array}{r}0.52 \\
\pm 0.09\end{array}$ & $\begin{array}{r}0.77 \\
\pm 0.12\end{array}$ & $\begin{array}{r}77.6 \\
\pm 7.8\end{array}$ \\
\hline
\end{tabular}

* Calculated from the results of electrophoretic separations.

$\dagger$ Determined by the method of Dole (7).

$\ddagger$ On albumin separated from serum at 60 per cent saturation with ammonium sulfate.

the sera from the first 12 cases of nephrotic syndrome which were fractionated with ammonium sulfate solution (Figure 1). The plot indicates that the percentage of total UFA bound to al- bumin is reduced with rise of lipid or decrease of albumin concentration in the serum.

Table II also includes the results of representative experiments in which the potassium bromide

TABLE II

Distribution of UFA among serum lipoproteins

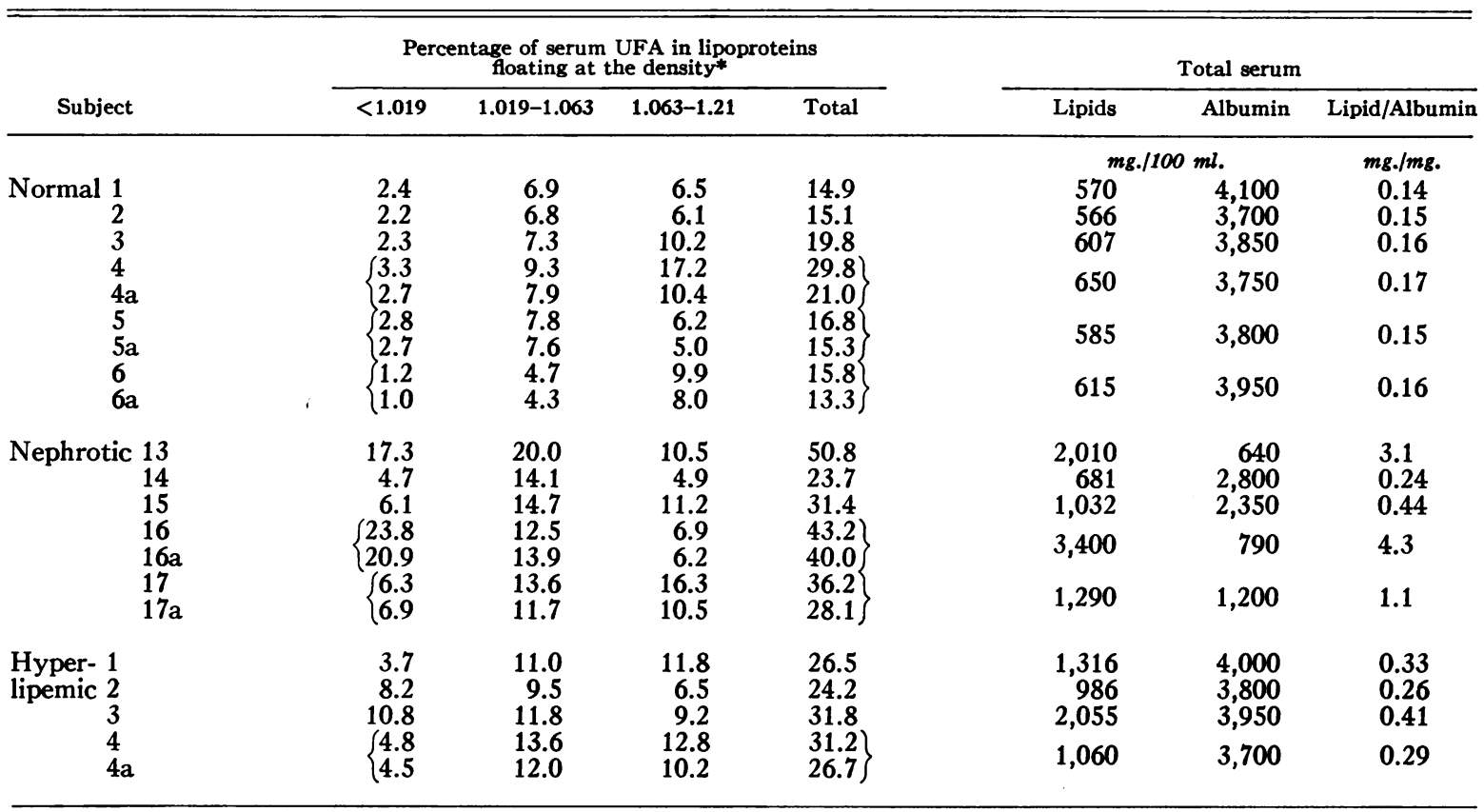

* Solutions of potassium bromide were used to bring the sera to proper density except in experiments indicated by suffix a. In these sera deuterium oxide was added to density of $1.063 \mathrm{Gm}$. per ml. or a 50 per cent solution of sucrose in deuterium oxide for the density of $1.21 \mathrm{Gm}$. per $\mathrm{ml}$. In the latter case the centrifugation time in the Spinco No. 40.3 rotor was extended to 48 hours. 


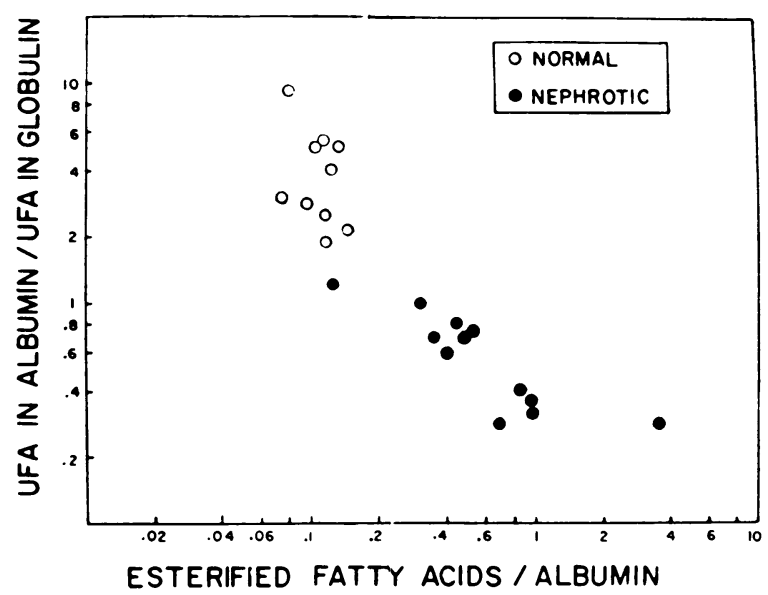

Fig. 1. Distribltion of Unesterified Fatty Acids (UFA) Between Albuina and Globulin is Relation to the Esterified Fatty Acid to Albumix Coxcentration Ratio in Normal and Nephrotic Sera

solutions employed for lipoprotein flotation were replaced by deuterium oxide solutions. These experiments were performed in order to test whether the high ionic strength of solutions (ammonium sulfate or potassium bromide) used to separate the albumin and lipoproteins affected the UFA distribution equilibrium in the serum. As shown in Table II small differences in the UFA content were apparent, particularly in the case of the $\mathrm{d}=1.019$ to 1.063 and $\mathrm{d}=1.063$ to 1.21 lipoprotein fractions. This points to the fact that the experimental procedure under which lipoprotein separation was carried out may cause some alterations in UFA partition. One cannot extrapolate the results obtained in any one method to another. However, within any given fractionation procedure, the results are valid for relative comparisons of UFA partition in the normal and pathologic state.

Electrophoretic pattern of nephrotic sera-Effect of added albumin

Moving boundary electrophoresis of nephrotic sera (Figure 2, $\mathrm{A}$ and $\mathrm{C}$ ) showed the characteristic irregularity in the alpha.,- and beta-globulin region. Either one or both of these fractions deviated from normal in respect to concentration and mobility. Their resolution was poor and sometimes an additional component of intermediate mobility was recorded. These observations are consistent with the hypothesis that enough UFA is bound to lipoproteins to displace them in the electrophoretic pattern. If this hypothesis is correct, restoring the UFA distribution towards normal should cause the electrophoretic mobilities of the serum lipoproteins to return to normal values. When UFA-poor albumin was added to nephrotic serum such a redistribution of UFA was indeed achieved. Furthermore, a striking change towards normal was observed in the electrophoretic pattern of the albumin enriched sera (Table III and Figure 2, B and D). There was a decrease in the electrophoretic mobility of some serum components, especially in the beta-globulin zone, which markedly improved the resolution of the alpha $2^{-}$and beta-globulin fractions. Where it was present, the intermediate "third" alpha component disappeared, most probably being merged with the beta globulin and representing the lipoprotein component of this fraction. In most cases studied, a significant increase in the beta-globulin concentration and

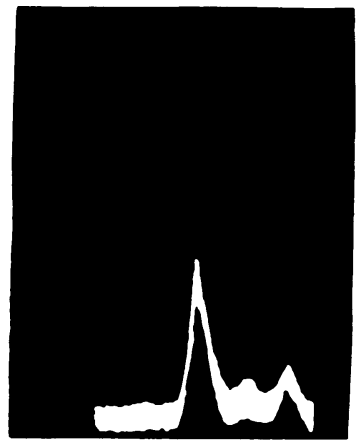

A

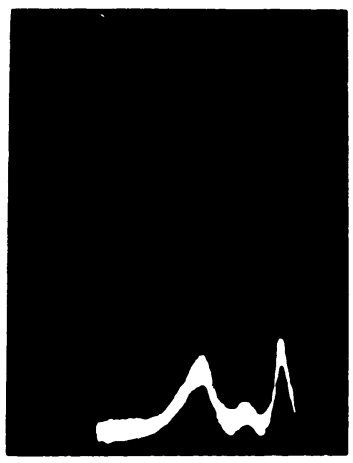

C

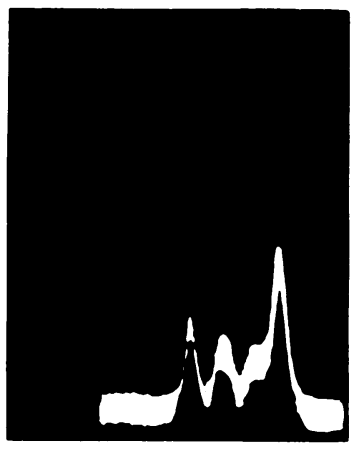

B

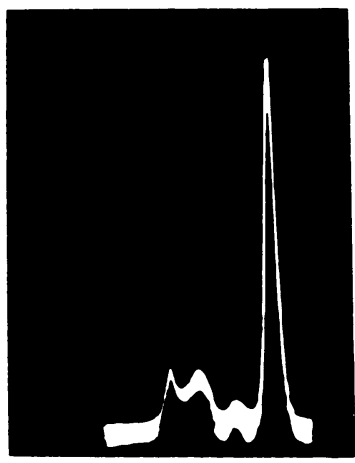

$\mathrm{D}$
Fig. 2. Ascending Boundary Patterns of Nepirrotic Syndrome Sera (Subjects No. 1 and 4)

$A$ and $C$, native serum; $B$ and $D$, albumin-enriched serum. In each picture the extreme right peak corresponds to albumin. 
TABLE III

Effect of enrichment with albumin on the electrophoretic mobility and concentration of protein fractions in nephrotic syndrome serum

\begin{tabular}{|c|c|c|c|c|c|c|c|c|c|c|c|c|c|c|c|c|}
\hline \multirow{4}{*}{$\frac{\text { Subject }}{\text { no. }}$} & \multicolumn{2}{|c|}{$\begin{array}{c}\text { Total serum } \\
\text { protein }\end{array}$} & \multicolumn{6}{|c|}{ Electrophoretic mobility } & \multicolumn{6}{|c|}{ Concentration } & \multirow{2}{*}{\multicolumn{2}{|c|}{$\begin{array}{l}\text { UFA* in } \\
\text { globulin fraction }\end{array}$}} \\
\hline & Native & $\begin{array}{l}\text { Albumin } \\
\text { enriched }\end{array}$ & Alb. & $\alpha_{1}$ & $\alpha_{2}$ & $\alpha_{3}$ & $\boldsymbol{\beta}$ & $\gamma \dagger$ & Alb. & $\alpha_{1}$ & $\alpha_{2}$ & $\alpha_{3}$ & $\boldsymbol{\beta}$ & $\gamma \dagger$ & & \\
\hline & \multicolumn{2}{|c|}{$\mathrm{Gm} . / 100 \mathrm{ml}$} & \multicolumn{6}{|c|}{$\mathrm{cm} \cdot .^{2} \mathrm{~V} .^{-1} \mathrm{sec} .^{-1} \times 10^{-5}$} & \multicolumn{6}{|c|}{$\mathrm{Gm} . / 100 \mathrm{ml}$} & $m E q . / L$ & $\%$ \\
\hline & 4.7 & 8.0 & $\begin{array}{l}6.1 \\
5.9\end{array}$ & $\begin{array}{l}5.3 \\
5.1\end{array}$ & $\begin{array}{l}4.2 \\
4.1\end{array}$ & & 2.7 & & $\begin{array}{l}1.41 \\
4.60\end{array}$ & $\begin{array}{l}0.75 \\
0.84\end{array}$ & $\begin{array}{l}2.54 \\
1.56\end{array}$ & & 1.02 & & $\begin{array}{l}0.378 \\
0.241\end{array}$ & $\begin{array}{l}63.0 \\
30.9\end{array}$ \\
\hline $2 \ddagger$ & 4.2 & 8.1 & $\begin{array}{l}6.5 \\
6.1\end{array}$ & $\begin{array}{l}5.9 \\
4.6\end{array}$ & $\begin{array}{l}4.8 \\
3.7\end{array}$ & 4.4 & $\begin{array}{l}3.3 \\
3.1\end{array}$ & & $\begin{array}{l}0.65 \\
4.25\end{array}$ & $\begin{array}{l}0.15 \\
0.15\end{array}$ & $\begin{array}{l}2.30 \\
2.00\end{array}$ & & $\begin{array}{l}1.36 \\
1.70\end{array}$ & & $\begin{array}{l}0.278 \\
0.111\end{array}$ & $\begin{array}{l}71.3 \\
19.5\end{array}$ \\
\hline 3 & 4.4 & 8.0 & $\begin{array}{l}6.7 \\
5.9\end{array}$ & & $\begin{array}{l}4.8 \\
3.8\end{array}$ & 4.4 & $\begin{array}{l}3.8 \\
2.5\end{array}$ & $\begin{array}{l}1.3 \\
1.3\end{array}$ & $\begin{array}{l}0.86 \\
4.20\end{array}$ & $\begin{array}{l}0.13 \\
0.16\end{array}$ & $\begin{array}{l}1.70 \\
1.76\end{array}$ & & $\begin{array}{l}1.56 \\
1.63\end{array}$ & $\begin{array}{l}0.15 \\
0.16\end{array}$ & $\begin{array}{l}0.309 \\
0.220\end{array}$ & $\begin{array}{l}73.4 \\
34.9\end{array}$ \\
\hline 7 & 4.8 & 7.5 & $\begin{array}{l}6.2 \\
6.0\end{array}$ & $\begin{array}{l}5.2 \\
4.7\end{array}$ & $\begin{array}{l}3.6 \\
3.7\end{array}$ & & 2.7 & & $\begin{array}{l}1.53 \\
4.15\end{array}$ & $\begin{array}{l}0.71 \\
0.75\end{array}$ & $\begin{array}{l}2.58 \\
1.60\end{array}$ & & 1.00 & & $\begin{array}{l}0.260 \\
0.206\end{array}$ & $\begin{array}{l}63.4 \\
36.8\end{array}$ \\
\hline 9 & 3.0 & $\begin{array}{l}4.0 \\
7.4\end{array}$ & $\begin{array}{l}6.4 \\
6.2 \\
6.0\end{array}$ & $\begin{array}{l}5.6 \\
5.2 \\
5.1\end{array}$ & $\begin{array}{l}5.2 \\
3.8 \\
3.6\end{array}$ & 4.3 & $\begin{array}{l}3.2 \\
2.8 \\
2.3\end{array}$ & & $\begin{array}{l}0.73 \\
1.52 \\
5.20\end{array}$ & $\begin{array}{l}0.38 \\
0.34 \\
0.21\end{array}$ & $\begin{array}{l}0.35 \\
1.30 \\
1.23\end{array}$ & 1.14 & $\begin{array}{l}0.40 \\
0.80 \\
0.84\end{array}$ & & $\begin{array}{l}0.398 \\
0.247\end{array}$ & $\begin{array}{l}76.4 \\
29.8\end{array}$ \\
\hline 11 & 4.1 & $\begin{array}{l}6.2 \\
9.2\end{array}$ & $\begin{array}{l}6.5 \\
6.3 \\
6.0\end{array}$ & $\begin{array}{l}5.2 \\
4.8 \\
4.8\end{array}$ & $\begin{array}{l}4.2 \\
3.8 \\
3.5\end{array}$ & & $\begin{array}{l}3.0 \\
2.9 \\
2.7\end{array}$ & & $\begin{array}{l}1.16 \\
3.32 \\
6.21\end{array}$ & $\begin{array}{l}0.25 \\
0.28 \\
0.33\end{array}$ & $\begin{array}{l}1.49 \\
1.00 \\
0.87\end{array}$ & & $\begin{array}{l}1.15 \\
1.59 \\
1.78\end{array}$ & & $\begin{array}{l}0.547 \\
0.329\end{array}$ & $\begin{array}{l}78.1 \\
33.3\end{array}$ \\
\hline $\begin{array}{l}\text { Mean } \pm S . D . \\
\text { of } 10 \text { normals }\end{array}$ & $\begin{array}{r}6.9 \\
\pm 0.5\end{array}$ & & & & & & & & $\begin{array}{r}3.55 \\
\pm 0.26\end{array}$ & $\begin{array}{r}0.30 \\
\pm 0.05\end{array}$ & $\begin{array}{r}0.79 \\
\pm 0.10\end{array}$ & & $\begin{array}{r}1.05 \\
\pm 0.12\end{array}$ & $\begin{array}{r}1.31 \\
\pm 0.22\end{array}$ & & $\begin{array}{r}22.4 \\
\pm 7.8\end{array}$ \\
\hline
\end{tabular}

* The amount of UFA in the globulins was derived by subtraction of the amount found on albumin.

$\neq$ In this serum a small prealbumin component was observed which disappeared on enrichment with albumin.

decrease in the alpha ${ }_{2}$-globulin concentration was recorded.

Paper electropherograms of nephrotic sera, stained with oil red $\mathrm{O}$ (Figure 3 ), lend additional evidence as to the lipoprotein nature of the beta-component, the mobility of which was most affected upon enrichment with UFA-poor albumin. They also hint that the migration rate of the alpha ${ }_{1}$ lipoprotein in nephrosis may be affected by its increased UFA content. However, accurate measurements of the mobility of this component could not be performed because of marked dilution of nephrotic, lipemic sera necessary for analysis in the moving boundary apparatus. The concentration of alpha ${ }_{1}$ lipoprotein in nephrotic serum is diminished (19) and its peak at such dilution is hardly discernible.

\section{DISCUSSION}

Measurement of UFA on ultracentrifugally separated serum lipoproteins demonstrates that these proteins are capable of binding significant portions of serum UFA. Thus, albumin does not appear to be the sole carrier of serum UFA despite very high association constant for the first $2 \mathrm{M}$ of UFA per $\mathrm{M}$ of protein (20). Taking the normal concentration of serum albumin as 0.6 $\mathrm{mM}$ per L., the amount of UFA which can be firmly bound to this first class of binding sites on albumin considerably exceeds the normal UFA level. The situation may therefore be regarded as a competition between the albumin and the lipoproteins for the available UFA. Such competitive interaction is indicated by the changing partition of UFA in serum with rising concentration ratio of lipoprotein to albumin, as exemplified in the pathologic conditions of nephrosis and hyperlipemia. In some of these sera with grossly distorted lipoprotein to albumin ratios, the UFA carried by lipoprotein may amount to more than half of total serum UFA.

Goodman and Shafrir (21) have quantitatively studied the interaction of five unesterified fatty acids with $d<1.019$ and $d=1.019$ to 1.063 lipoproteins. The studies were carried out by measuring the distribution of varying quantities of $\mathrm{C}^{\mathbf{1 4}}$ labeled lauric, palmitic, stearic, oleic and linoleic acids in an isolated albumin-lipoprotein system. These acids comprise about 80 per cent of normal serum UFA (22). The results of this study, when extrapolated to protein and UFA concentrations of normal serum, indicate that only about 1 per cent of the five acids cited would be bound to the low density $(\mathrm{d}<1.063)$ lipoproteins. Moreover, high ionic strength solutions were shown to significantly alter the fatty acid distribu- 


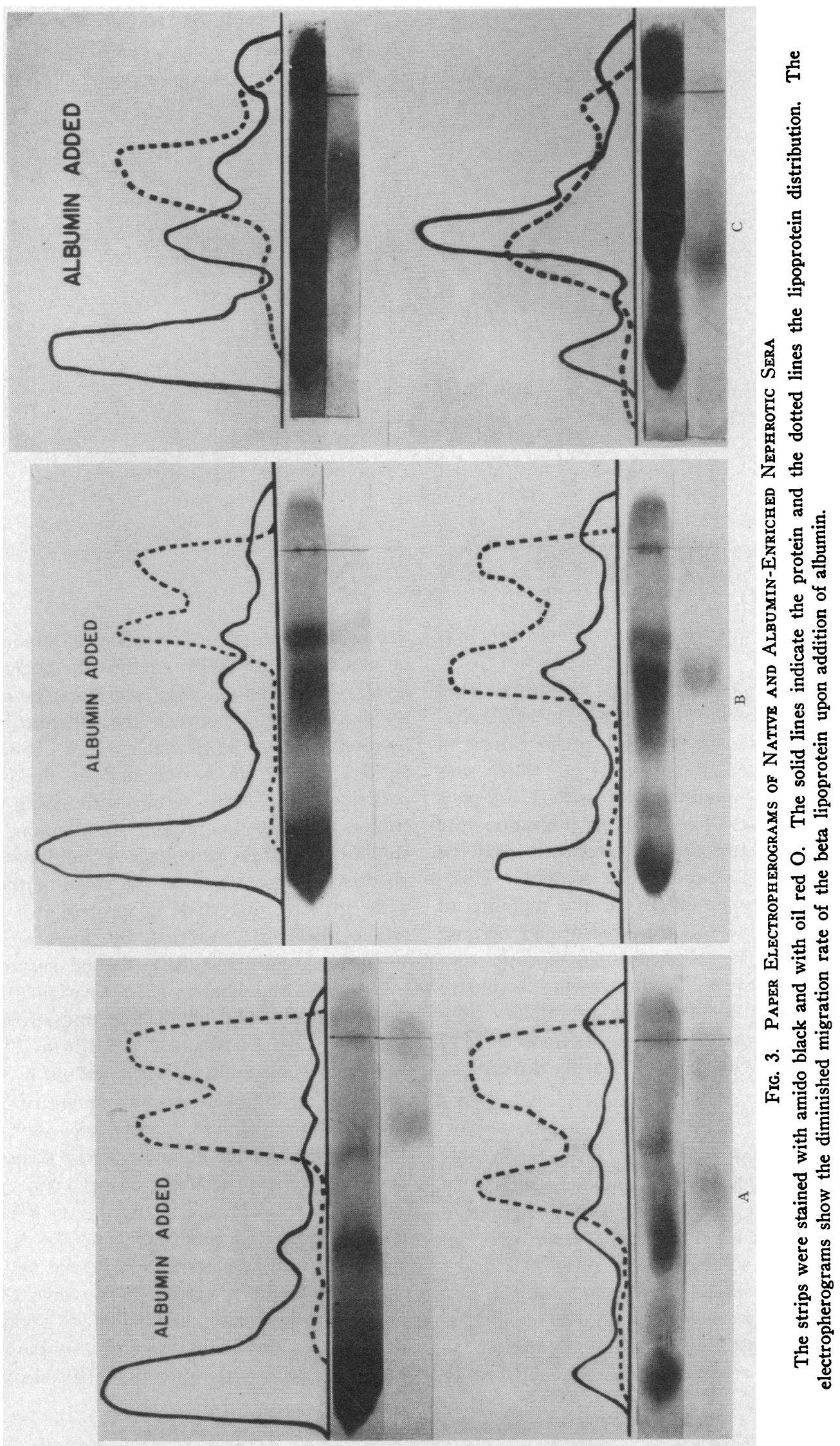


tion, resulting in a higher fraction of the fatty acid becoming associated with lipoprotein. These findings are in apparent contradiction to the results shown in Table II, where larger amounts of UFA were found with the lipoproteins and where flotation with potassium bromide and deuterium oxide as density media produced only small differences in the percentages of lipoprotein-bound UFA.

Similarly, Gofman and co-workers (23) measuring the UFA contents of extracts of salt-flotated lipoproteins by infrared spectrophotometry, reported still higher amounts of UFA associated with the lipoproteins.

It is therefore to be emphasized that in the results presented here the UFA content of the lipoprotein fractions was measured on the basis of the extractable and titratable acidity. It may be possible that some of the extracted acidity represents a non-UFA constituent. However, it is more probable that some of the other serum unesterified fatty acids not included in the above study (21) might distribute differently between albumin and lipoproteins. The discrepancy may be explained by assuming that a small fraction of serum UFA ( 5 to 10 per cent) is preferentially bound to the lipoproteins, its partition being negligibly affected by raising the ionic strength of the flotation medium. The possibility that fatty acids with chain length greater than 18 carbon atoms may constitute such a group is under current investigation.

The accelerating effect of UFA on the electrophoretic mobility of serum protein components has hitherto been demonstrated only in the presence of excess of UFA (4-6). In the experiments reported here on nephrotic syndrome serum, increased mobility of lipoprotein components was shown to persist despite normal UFA content. The increased mobility seems to be strongly associated with the shift in UFA partition equilibrium as caused by the abnormally low albumin and elevated lipoproteins. In nephrosis most of the lipoproteins are of molecular density less than $1.063(24,25)$. This lipoprotein group normally migrates in the beta-globulin zone, although according to Kunkel and Trautman (26) it includes some lipoproteins with alpha $_{2}$-globulin mobility. Therefore the most pronounced effect of UFA made available for binding by the lipoproteins will be exerted on that fraction in particular. The additional negative surface charge acquired by the UFA-rich nephrotic beta lipoprotein appears to be sufficient to displace it totally or partially into the alpha ${ }_{2}$-globulin zone. It remains to be determined whether the effect of UFA on the mobility of beta lipoprotein will be more pronounced in the type of nephrosis in which the lipoproteins of $\mathrm{d}=1.019$ to 1.063 rather than those of $\mathrm{d}<$ 1.019 are elevated (24).

It is pertinent that markedly increased lipid content of alpha $_{2}$-globulins was observed by Ott in two patients with analbuminemia (27). This was considered to be due to partial displacement of the beta lipoproteins, which in such cases appear to be sole carriers of serum UFA.

Upon enrichment of nephrotic serum with UFA-poor albumin, considerable amounts of UFA left the globulin fraction and concomitantly the beta lipoproteins resumed their normal migration rate. This reversal of the rapid migration rate seems to warrant a general conclusion regarding the appreciable quantity of lipoproteins migrating ahead of the beta-globulin region in sera with seriously distorted lipoprotein to albumin ratios. Such phenomena should be considered as due to increased mobility of beta-lipoprotein rather than to the appearance of a new lipoprotein entity. While this consideration may help interpret abnormal electrophoretic lipoprotein patterns, the physiologic significance of the competition awaits further elucidation.

\section{SUM MARY}

Albumin- and lipoprotein-bound unesterified fatty acids (UFA) in normal and nephrotic sera were measured. The total UFA content of nephrotic sera was within the normal range but the proportion of UFA bound to lipoproteins was considerably higher than in normal sera. The partition of UFA appeared to be dependent on the lipoprotein to albumin concentration ratio in the serum.

The electrophoretic resolution of alpha and beta components, as well as UFA partition in nephrotic serum, was restored toward normal by the in vitro addition of UFA-poor albumin. This was due to the decrease in the electrophoretic mobility of the beta lipoprotein component in the albumin enriched serum. It is concluded that 
the increased UFA content of the lipoproteins may be the principal cause of excess lipoproteins appearing ahead of beta zone in the electrophoretic pattern of sera with grossly distorted lipoprotein to albumin ratios.

\section{REFERENCES}

1. Swahn, B. Studies on blood lipids. Scand. J. clin. Lab. Invest. 1953, 5, Suppl. 9.

2. Fredrickson, D. S., and Gordon, R. S., Jr. Transport of fatty acids. Physiol. Rev. 1958, 38, 585.

3. Gordon, R. S., Jr. Interaction between oleate and the lipoproteins of human serum. J. clin. Invest. 1955, 34, 477.

4. Herbst, F. S. M., Lever, W. F., Lyons, M. E., and Hurley, N. A. Effects of heparin on the lipoproteins in hyperlipemia. An electrophoretic study of the serum alpha and beta lipoproteins after their separation by fractionation of the plasma proteins or ultracentrifugal flotation. J. clin. Invest. 1955, 34, 581.

5. Mora, R., Rebeyrotte, P., and Polonovski, J. Influence des substances tensioactives sur la mobilité électrophorétique des lipoprotéides plasmatiques. Bull. Soc. Chim. biol. (Paris) 1955, 37, 957.

6. Laurell, S. The effect of free fatty acids on the migration rates of lipoproteins in paper electrophoresis. Scand. J. clin. Lab. Invest. 1955, 7, 28.

7. Dole, V. P. A relation between non-esterified fatty acids in plasma and the metabolism of glucose. J. clin. Invest. 1956, 35, 150.

8. Shafrir, E. To be published.

9. Gordon, R. S., Jr. Unesterified fatty acid in human blood plasma. II. The transport function of unesterified fatty acid. J. clin. Invest. 1957, 36, 810.

10. Weichselbaum, T. E. An accurate and rapid method for the determination of proteins in small amounts of blood serum and plasma. Amer. J. clin. Path., Tech. Sect. 1946, 10, 40.

11. Bragdon, J. H. Colorimetric determination of blood lipides. J. biol. Chem. 1951, 190, 513.

12. Stern, I., and Shapiro, B. A rapid and simple method for the determination of esterified fatty acids and for total fatty acids in blood. J. clin. Path. 1953, $6,158$.

13. Selden, G. L., and Westphal, U. Non-esterified higher fatty acids in serum of $\mathrm{CCl}_{4}$-treated and normal rats and other species. Proc. Soc. exp. Biol. (N. Y.) $1955,89,159$.
14. Havel, R. J., Eder, H. A., and Bragdon, J. H. The distribution and chemical composition of ultracentrifugally separated lipoproteins in human serum. J. clin. Invest. 1955, 34, 1345.

15. Bragdon, J. H., Havel, R. J., and Boyle, E. Human serum lipoproteins. I. Chemical composition of four fractions. J. Lab. clin. Med. 1956, 48, 36.

16. Cohn, E. J., Hughes, W. L., Jr., and Weare, J. M. Preparation and properties of serum and plasma proteins. XIII. Crystallization of serum albumins from ethanol-water mixtures. J. Amer. chem. Soc. $1947,69,1753$.

17. Goodman, D. S. Preparation of human serum albumin free of long-chain fatty acids. Science 1957, 125, 1296.

18. Köiw, E., Wallenius, G., and Grönwall, A. Paper electrophoresis in clinical chemistry. A comparison with Tiselius' original method. Scand. J. clin. Lab. Invest. 1952, 4, 47.

19. Adlersberg, D., Bossak, E. T., Sher, I. H., and Sobotka, H. Electrophoresis and monomolecular layer studies with serum lipoproteins. Clin. Chem. 1955, 1, 18.

20. Goodman, D. S. The interaction of human serum albumin with long-chain fatty acid anions. J. Amer. chem. Soc. 1958, 80, 3892.

21. Goodman, D. S., and Shafrir, E. The interaction of human low density lipoproteins with long-chain fatty acid anions. J. Amer. chem. Soc. In press.

22. Dole, V. P. Transport of non-esterified fatty acids in plasma in Chemistry of Lipides as Related to Atherosclerosis, Irvine H. Page, Ed. Springfield, I1l., Charles C Thomas, 1958, p. 191.

23. Gofman, J. W., DeLalla, O., Glazier, F., Freeman, N. K., Lindgren, F. T., Nichols, A. V., Strisower, B., and Tamplin, A. R. The serum lipoprotein transport system in health, metabolic disorders, atherosclerosis and coronary heart disease. Plasma (Milano) 1954, 2, 413.

24. Lewis, L. A., and Page, I. H. Electrophoretic and ultracentrifugal analysis of serum lipoproteins of normal, nephrotic and hypertensive persons. Circulation 1953, 7, 707.

25. Baxter, J. H., Goodman, H. C., and Havel, R. J. Hyperlipidemia of nephrosis (abstract). J. clin. Invest. 1957, 36, 873.

26. Kunkel, H. G., and Trautman, R. The alpha lipo- $^{-}$ proteins of human serum. Correlation of ultracentrifugal and electrophoretic properties. J. clin. Invest. 1956, 35, 641.

27. Ott, H. Das Blutserum bei Analbuminämie. Z. ges. exp. Med. 1957, 128, 340. 